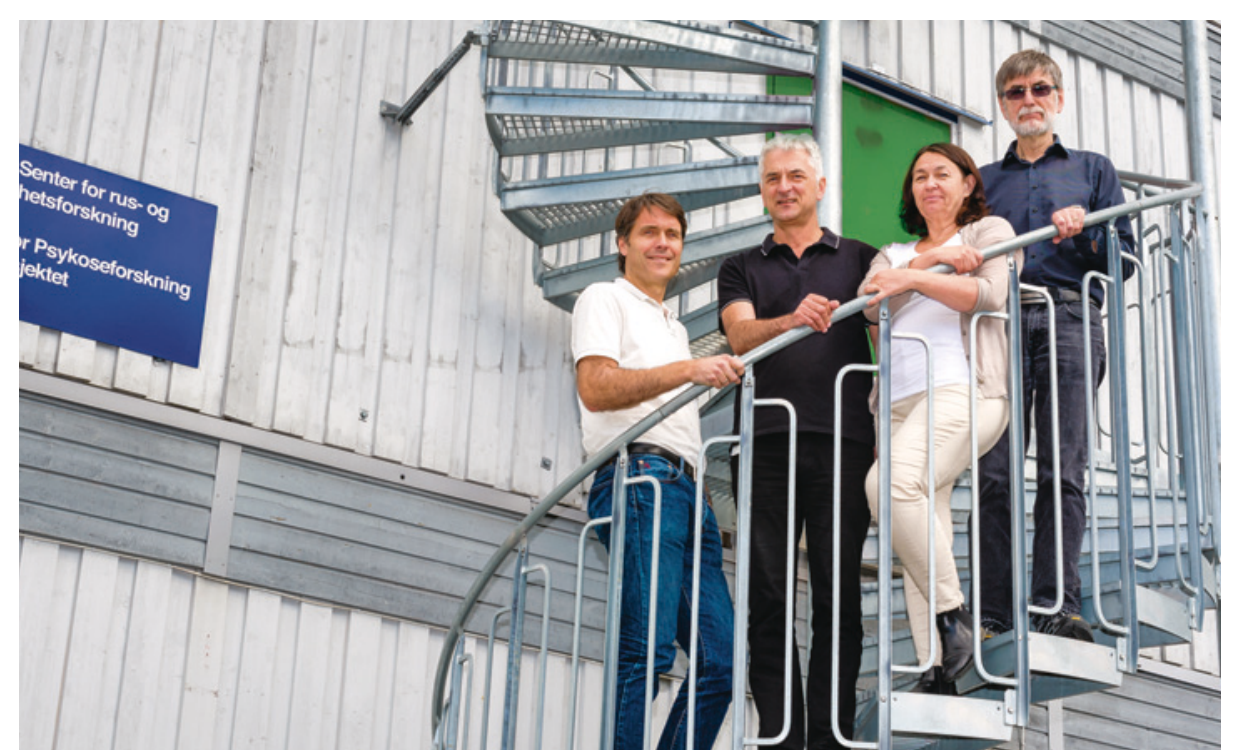

Fra venstre: Ole A. Andreassen, Srdjan Djurovic, Ingrid Melle og Erik Jönsson er noen av de norske forskerne som har bidratt i den store internasjonale studien. Foto: Øystein H. Horgmo, Universitetet i Oslo
Ordforklaringer

Heritabilitet: Arvelighet - andel av sykdomsrisiko som skyldes genetiske faktorer.

Genomvide assosiasjonsstudier: Studier av et høyt antall vanlige genetiske varianter (ofte over en million) hos et stort antall personer for å identifisere genvarianter som er forbundet med bestemte egenskaper eller sykdom.

Genvariant: En av mange alternative former av det samme genet eller samme genetiske posisjon.

\title{
Schizofreni er knyttet til mange genvarianter
}

Norske forskere har bidratt til å påvise over hundre genvarianter som gir økt risiko for schizofreni.

Schizofreni har høy grad av arvelighet, men fremdeles er de genetiske faktorene i hovedsak ukjente. I en fersk artikkel i tidsskriftet Nature fremlegges resultatene av en internasjonal studie med nesten 37000 pasienter med schizofreni og over 113000 kontrollpersoner (1). Dette er den største studien som er gjort innen gener og schizofreni.

Gjennom DNA-analyser identifiserte forskerne 128 genvarianter som gir økt risiko for schizofreni, hvorav 83 ikke er beskrevet tidligere. Risikoen var særlig økt for gener som uttrykkes i nevroner og hjernevev. Flere av de identifiserte genene uttrykkes også i vev som spiller viktige roller i immunforsvaret.

- At vi finner økt risiko ved gener som uttrykkes i hjernen, gir funnene biologisk troverdighet, sier Ole A. Andreassen, som har ledet den norske delen av studien. - Funnene gir også støtte til den antatte koblingen mellom immunsystemet og schizofreni. Resultatene må følges opp for å finne mekanismen for hvordan genvariantene påvirker sykdomsutvikling. Slik vil vi kunne få økt forståelse av patofysiologien ved schizofreni.

- Vi fant også at den genetiske risikoen for schizofreni defineres av et stort antall genvarianter, såkalt polygen arkitektur. Hver av disse genvariantene har liten effekt i seg selv, men i kombinasjon kan de lede til sykdom. Slike kombinasjoner er vanskelige å oppdage, men ved å studere et stort antall personer i genomvide assosiasjonsstudier, kan slike effekter påvises, sier Andreassen.

\section{Internasjonalt samarbeid}

Studien er gjennomført av i regi av Schizophrenia Working Group of the Psychiatric Genomics Consortium, som er et verdensomspennende samarbeidsprosjekt for schizofreniforskning. Ole A. Andreassen, professor i psykiatri ved Universitetet i Oslo og overlege ved Oslo universitetssykehus, har ledet det norske arbeidet, som utgår fra NORMENT - KG Jebsen senter for psykoseforskning. De øvrige norske forfatterne er Ingrid Melle (Oslo), Ingrid Agartz (Oslo), Srdjan Djurovic (Oslo og Bergen), Erik G. Jönsson (Stockholm og Oslo), Inge Joa (Stavanger) og Morten Mattingsdal (Kristiansand).

\section{Hanne Støre Valeur}

Tidsskriftet

\section{Litteratur}

1. Andreassen OA, Melle I, Agartz I et al. Schizophrenia Working Group of the Psychiatric Genomics Consortium. Biological insights from 108 schizophrenia-associated genetic loci. Nature 2014; e-publisert 22.7.2014.

Publisert først på nett.

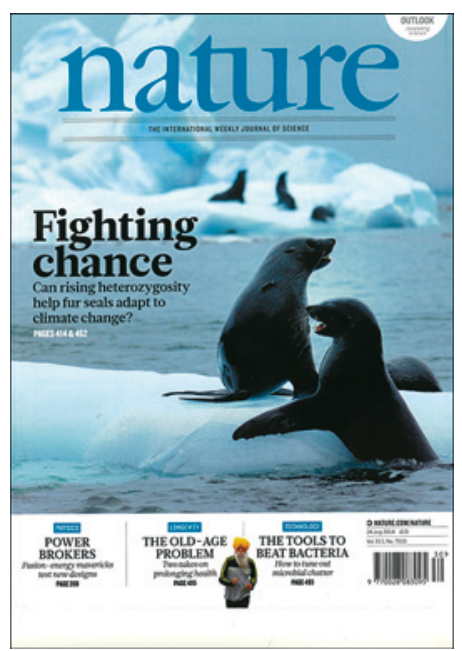

Artikkelen ble e-publisert i det prestisjetunge tidsskriftet Nature 24.7.2014 